- бақыт. Ендеше, жастарды орта ғасыр туындылары тіліндегі паремиялогиялық бірліктер арқылы тәрбиелеуде мынадай міндеттер бар. Олар:

1. Ислам дәуірі мұралары бойынша ер балалар мен қыз балалар тәрбиесіне бағытталған жүйелі жоспар құру;

2. Ислам дәуірі мұраларындағы ана тілге, елге, жерге деген сүйіспеншілікті арттыра түсетін тілдік бірліктерге негізделген онлайн форматтағы іргелі іс-шараларды айқындау;

3. Ислам дәуірі мұралары негізінде өскелең ұрпақты ұлтжандылық рухта тәрбиелеуге жетелейтін ісшараларды дәстүрлі түрде жүргізуді қолға алу;

4. Бүгінгі әрбір жас буын өкілін өз Отанын қастерлеуге, туған жерін құрметтеуге, ата-бабаның озық салтдәстүрлерінің құндылығын мақтаныш тұтуға баулуға мүмкіндік жасайтын нақтылы іс-шараларды анықтау. Аталған міндеттерді орындау және оларды дамыта отырып жүзеге асыру жастарға тәрбие беру жұмыстарының бірізді әрі жүйелі түрде жүруіне мүмкіндік береді. Сондай-ақ жас ұрпаққа тәрбие берудің тиімділігі артады. Бұдан түйер түйін: бүгінгі тәрбие жұмысы түркі халқына ортақ ислам дәуірі мұраларындағы ұрпақ тәрбиесіне қатысты ой-пікірлермен байланысты жүзеге асырылуы абзал.

Қорытынды. Бүгінгі ел жастарының “толық адами” (Абай) келбетін қалыптастыруда тәрбиенің этнопсихологиялық негіздері мен түркі мұраларындағы тәрбиеге қатысты мәселелерді бір арнаға тоғыстырып, Абай Құнанбаев, Шәкәрім Құдайбердіұлы, Ахмет Байтұрсынов т.б. ұлт ойшылдары мен қоғам қайраткерлерінің еңбектеріндегі ұрпақ тәрбиесі туралы ой-пікірлерді басшылыққа ала отырып, тәлім-тәрбие беру жоспарын жасау және орындау жас ұрпақтың өнегелі болуына мол мүмкіндік береді. Түйіндей келгенде, ұлттың ұрпақтан ұрпаққа үзілмей келе жатқан құндылықтарын жас ұрпақ бойына сіңіру - мемлекет мүддесі, ел игілігі.

Ұлт тіліндегі паремиялогиялық бірліктер - халықтың өмірлік іс-тәжірибесі, күнделікті тіршілік барысында жасаған пайымдарының өткір де ықшам мәйегі. Ал ислам дәуірінде жарық көрген көркем туындылар тіліндегі қанатты сөздер, мақал-мәтелдер - "адам мен қоғам” арақатынасының ажырамас бірлікте екендігін сипаттайтын, тәрбиелік мәні жоғары паремиялогиялық бірліктер. Оған баса мән беріп, жіті қарастыру профессор Әбжан Құрышжанұлының зерттеулерінен айқын танылады.

Пайдаланылван ддебиеттер тізімі:

1 Құрышжанұль Ә. Ескі түркі жазба ескерткіштері. - Алматы: Қайнар, 2001. - 472 б.-кітап

2 Қазақ̆стан Республикасының Конституциясы. //www.akorda.kz/kz/official_documents/constitutionинтернет

3 Сәдуақ̆асұлы Ә. Қазақ этнопедагогикасы мен этнопсихологиясының кейбір мәселелері. - Aлматы: Дайырбаспа, 2012. - 306 б.-кітап

4 Қашқари М. Түрік тілінің сөздігі: (Диуани лұват-ит-түрік): 3 томдық шывармалар жинавы / Қазақ тіліне аударван, алвы сөзі мен вылыми түсініктерін жазван А.Егеубай. - Алматьл: “Хантәнірі”., - 528 бет. .кiman

5 Адамбаев Б. Қазақ хальққ әдебиеті: мақал-мәтелдер. - Алматы: «Ғылымм», 1996. .-кітап References:

$1 \quad$ Kurysjanuly A. Eskı turkı jazba eskertkısterı. - Almaty: Kainar, 2001. - 472 b.-kıtap

2 Kazakstan Respublikasynyn Konstitusiasy. //www.akorda.kz/kz/official_documents/constitution-internet

3 SAduaKasuly A. Kazak etnopedagogikasy men etnopsihologiasynyn keibır mAselelerı. - Almaty: Daiyrbaspa, 2012. - 306 b.-kitap

4 KasKari M. Turık tılının sozdıgl: (Diuani lugat-it-turık): 3 tomdyK sygarmalar jinagy / Kazak tılıne audargan, algy sozı men gylymi tusınıkterın jazgan A.Egeubai. - Almaty: "HantAnırl”., - 528 bet. .-kitap

5 Adambaev B. Kazak halyK Adebietı: maKal-mAtelder. - Almaty: "Gylym», 1996. .-kıtap

МРНТИ 16.31.61

\author{
https://doi.org/10.51889/2021-1.1728-7804.11 \\ Ibrayeva Zh., ${ }^{1}$ Zhaksylykkyzy $K^{2}$ \\ ${ }^{1,2}$ Al-Farabi Kazakh National university, \\ Almaty, Kazakhstan
}

\title{
THE ROLE OF NEUROLINGUISTIC RESEARCH IN THE STUDY OF BILINGUALISM
}

\section{Abstract}

The use of two or more languages is common in most countries of the world. However, until recently, bilingualism was considered as a factor that complicates the processing of speech, cognition and the brain. In the past 25 years there have been a surge in research on bilingualism, including the study, mastery and processing of languages, their cognitive and neural foundations, and the lifelong implications of bilingualism for cognition and the brain. Contrary to the belief that bilingualism complicates the language system, new research demonstrates that all known and used languages become part of the same language system. The interactions that occur when using the two languages have conseKuences for mind and the brain and indeed for language processing itself but these implications are not additive. 
Thus, bilingualism helps to uncover the fundamental architecture and language processing mechanisms that locates differently in monolingual speakers.

Keywords: neurolinguistics, bilingualism, multilingualism, neuroscience, first language, second language, language acKuisition

\author{
Ибраева Ж.К., ${ }^{1}$ Жақ̧сылыққызызы К.. ${ }^{2}$ \\ ${ }^{1,2}$ Әл-Фараби атындавы Қазақ ұлттыққ университеті, \\ Алмать, Қазақстан
}

\title{
БИЛИНГВИЗМДІ ЗЕРТТЕУ ҮДЕРІСІНДЕГІ НЕЙРОЛИНГВИСТИКАЛЫҚ ЗЕРТТЕУЛЕРДІН РӨЛІ
}

\section{Аңцдатпа}

Екі немесе одан да көп тілді қолдану әлемнің көптеген елдерінде кеңінен таралған жағдай. Дегенмен, осы кезге дейін билингвизм сөйлеуді, таным мен миды өңдеуді қиындататын фактор ретінде қарастырылып келді. Соңғы 25 жылда билингвизм туралы, оның ішінде тілдерді зерттеу, меңгеру және өңдеу мәселелері мен олардың когнитивтік және жүйке астары негіздерін қарастыру, билингвизмнің таным мен миға әсері туралы зерттеулер қарқынды жүрді. Билингвизм тілдік жүйені күрделендіреді деген көзқарастарға қайшы, қазіргі таңда адам меңгеріп, қолданатын тілдердің барлығы мида бір тілдік жүйеге енетіндігін көрсететін жаңа зерттеулер жеткілікті. Екі тілді қолданған кезде туындайтын өзара әрекеттесулер ақыл-ой мен миға, әсіресе, тілдің өңделуіне әсер етеді, бірақ ол әсерлер аддитивті емес. Осылайша, қостілділік бір тілді иеленушілердің миында өзгеше орналасқан фундаменталды архитектура мен тілді өңдеу механизмдерін ашуға көмектеседі.

Түйін сөздер: нейролингвистика, билингвизм, көптілділік, нейроғылым, бірінші тіл, екінші тіл, тілді меңгеру

\author{
Ибраева Ж.К., Жаксыльиққызы К.. \\ ${ }^{1,2}$ Казахский национальный университет имени аль-Фараби, \\ Алматы, Казахстан
}

\section{РОЛЬ НЕЙРОЛИНГВИСТИЧЕСКИХ ИССЛЕДОВАНИЙ В ПРОЦЕССЕ ИЗУЧЕНИЯ БИЛИНГВИЗМА}

\begin{abstract}
Аннотация
Использование двух или более языков распространено в большинстве стран мира. Тем не менее, до недавнего времени билингвизм считался фактором, усложняющим обработку речи, познания и мозга. Последние 25 лет стали свидетелями всплеска исследований двуязычия, в том числе изучения, овладения и обработки языков, их когнитивных и нейронных основ, а также последствия билингвизма для познания и мозга на протяжении всей жизни. Вопреки мнению о том, что двуязычие усложняет языковую систему, в нынешнее время достаточно новых исследований, что все приобретенныее и используемые языки становятся частью одной языковой системы в мозге. Взаимодействия, возникающие при использовании двух языков, имеют последствия для разума и мозга и для самой языковой обработки, но эти последствия не аддитивные. Таким образом, двуязычие помогает раскрыть фундаментальную архитектуру и механизмы языковой обработки, которые иным образом расположены у одноязычных носителей.
\end{abstract}

Ключевые слова: нейролингвистика, билингвизм, многоязычие, нейронаука, первый язык, второй язык, усвоение языка

Introduction. Neurolinguistics is a branch of the science that emerged at the intersection of cognitive neuroscience and linguistics, which is a part of a broader field called neuroscience together with many other fields such as systemic, motor, sensory, cellular and others. Neurolinguistics can be divided into two fields:

1. mastering/acKuisition and processing of speech;

2. language disorders.

As it is widely known, the study of language took a certain biolinguistic direction only in the 1950s with the emergence of the generative grammar of Noam Chomsky the neurophysiological characteristics of healthy people (in terms of a linguistic nature), that is, understanding the relationship between language and the brain only began specifically explored in the late 1980s with the introduction of non-invasive cognitive assessment methods that opened up new facets of language learning.

It is commonly known that bilinguals are people who actively use more than one language but bilingualism arises in different ways. Some people become familiar with two languages from birth and continue to use both languages throughout their lives. Early bilingual people may live in a bilingual environment where they are users of most languages or in a context in which only one of the two languages is used by most speakers. Other bilingual people learn a second language (L2) only in early childhood when the mother tongue is firmly entrenched. Similar to early 
bilinguals, these later bilinguals can live in a variety of environments in which most people become bilingual or in which only a few become bilingual. Table 1 describes the classification of bilingualism proposed by V.P. Belyanin.

Table 1. Classification of bilingualism by V.P. Belyanin

\begin{tabular}{|c|c|c|}
\hline \multicolumn{3}{|c|}{ Bilingualism } \\
\hline national & individual & \\
\hline natural (domestic) & artificial (academic) & \\
\hline \multicolumn{3}{|l|}{ According to age } \\
\hline early & late & \\
\hline \multicolumn{3}{|c|}{ By the number of performed actions } \\
\hline Receptive (perceiving) & Reproductive (reproducing) & Productive (producing) \\
\hline
\end{tabular}

Differences between bilinguals arising from the study of the history and context of language use are important but differences in the languages themselves, as well as in the level of proficiency and relative dominance, which is used with each language, are also important $[1,83]$.

Methods. The article consists of two parts: theoretical and practical. The theoretical part is an overview of such issues: types of bilinguals, bilingualism, the influence of age on the acKuisition of L2 and the level, lateral dominance in bilinguals. Research methods are mainly reflected in the practical part. During the study, methods of mass collection, sorting, comparison of materials were used to collect and analyze the experiments. It is vivid that the results obtained by analyzing the performed experiments have a high degree of accuracy. Indeed, depending on the results of specific tasks the researcher can accurately study the approach to solving many open Kuestions in the field of neurolinguistics.

Research results. The problem of linguistic laterality in multilingual people has been discussed in this area for decades. Several hypotheses about L2 learning suggest more right-brain involvement in multilingual versus monolingual. However, tests for laterality in multilingual people have remained inconclusive on this issue. Multilingual participants as monolingual participants tend to exhibit left hemispheric lateralization for all languages, but the strength of this laterality may appear weaker in multilingual than in monolingual participants. In some studies, in multilingual people, the right hemisphere appears to be more active during L2 processing compared to L1 (first language) processing.

Linguistic distance and specific features of the language, non-native status, type of language task and the age of acKuisition of L2 seem to affect the degree of lateralization in multilingual people. Regarding the linguistic distance between multilingual languages, D'Anselmo, Reiterer, Zuccarini, Tommasi and Brancuchi reported that bilingual speakers who speak possibly more similar languages (German and English) show a greater left hemisphere advantage in L2 compared to L1, while bilinguals with less similar languages (Italian and English) showed no difference in the degree of laterality between L1 and L2 [2, 1190]. Early exposure to two languages can influence lateralization patterns if languages are also structured differently. When English was tested in bilinguals with L1 - Hebrew and L2 - English, who learned both languages very early showed an advantage of the left hemisphere while performing a semantic task where monolingual Hebrews also demonstrate an advantage in the left hemisphere but the monolingual English showed an advantage of the right hemisphere [3, 909]. Metuki et al. suggested that Hebrew has the linguistic characteristics that affect the lateralization of semantic processing in Hebrew affect how bilingual participants processed a task in English. Workman, Brookman, Mayer, Rees, and Bellin attributed lateral differences in multilinguals to specific language effects, showing greater left-hemispheric asymmetry in Welsh words than English words, regardless of whether the participants predominated in Welsh or English [4, 297]. However, this explanation is inconsistent with the results of Grossi, Savill, Thomas and Thierry, who while also studying Welsh-English bilinguals found that large left hemisphere asymmetries were associated with large L2 experiences rather than bilingual properties [5, 130].

Other studies have shown that the age of L2 mastery modulates laterality indices in bilinguals, although not always in the same way with early bilinguals sometimes showing greater participation of the right hemisphere and later bilinguals sometimes demonstrating this pattern [6, 445].

A study by Zou et al. suggests that second language acKuisition may actually increase right hemisphere engagement during L1 processing. They found that bimodal bilinguals who spoke Chinese exhibited greater right-brain involvement in their L1 compared to monolinguals. There can also be lateral differences in how different aspects of the language are processed [7, 1371]. Pillai et al. observed a large right-brain involvement for the phonological tasks of L2 but not for the semantic tasks in the L2 of the participants or for any of the tasks in L1 [8, 569]. According to the above material it is evident that the Kuestion of linguistic laterality in bilinguals has not been resolved yet. Likewise, the Kuestion of whether the brain subseKuently processes language in the same areas of the brain as the native language has sparked a large body of research with evidence supporting both sides of the Kuestion. Many have demonstrated highly overlapping cortical activation patterns when a bilingual person performs a task in both languages However, differences were also found, such as differences in the total amount of cortical activation in the brain, with L2 showing more activation than L1 as well as L1 activation in certain areas not found to be active when L2 was actively used (Dehaene et al., 1997; Halsband, Krause, Sipila, Teras, “ \& Laihinen, 2002; Perani et al., 1996). These results led the 
researchers to conclude that the same brain regions that are used for L1 processing are also used for L2 processing, but the increased intensity of activation and the recruitment of some additional areas, such as the prefrontal region, indicate greater complexity, as well as the need to increase cognitive resources and control when using L2. Research on multilingualism has largely confirmed these results. Vingerhoets et al. conducted an experiment on three language tasks: fluency, picture naming, and reading comprehension in a multilingual Dutch-French-English group and found that overall, the three languages affected the same cortical regions, but less experienced L2 participants recruited additional areas of the brain that are not involved during the execution of tasks L1. Two other studies with multilingual participants showed similar results [9, 2189]. Detailed evidence for the existence of different processing mechanisms for multilinguals comes from studies that observes more details of the impact of L2 proficiency and age of acKuisition of L2.

\section{Influence of age on the acKuisition of $\mathrm{L} 2$ and level}

While the age of second language acKuisition has a long history of psycholinguistic and neurolinguistic research on bilingualism, the level of second language proficiency has recently been of interest. Of course, these two concepts are often related but in the case of bilingual L2 students who do not speak two languages at the same level can also dissociate.

\section{The level of $\mathrm{L} 2$ proficiency}

Researchers who carefully monitored their participants' proficiency level found a high degree of overlapping activation for L1 and L2 in high-level bilinguals and less overlap for bilinguals with low proficiency. Studies comparing language activation patterns of multilingual people have also confirmed that language proficiency plays a significant role in how the brain processes languages in later bilinguals.

Brain activation patterns in multilingual people with lower proficiency in their non-native language tend to be more extensive in space and/or more intense than in people with higher proficiency in the language. In such participants several studies have found additional activated areas during L2 processing in the prefrontal areas in the left temporal lobe (Kim et al., 2002), cerebellum parietal cortex basal ganglia on both sides (Abutalebi et al., 2012; Liu et al.., 2010) and wider involvement of the right hemisphere (Park et al., 2012; Pillai et al., 2004). In a meta-analysis using an estimate of the likelihood of activation Sebastian et al concluded that high-proficiency bilinguals exhibit similar activation patterns in both languages, while low and moderate proficiency bilinguals exhibit smaller, more widely distributed activation clusters when performing a language task in L2 compared to L1. Indefrey hypothesized that increased activation in the low to medium proficiency group indicates less automatic and more labor intensive processing reKuired when bilingual people perform a language task in their non-native, less professional language [10, 289].

Thus, a broad look at these studies makes it clear that at a lower level of fluency of L2 the brain processes L2 differently than it does in the first but that as the level of proficiency in this language increases these differences may disappear. D. W. Green described this as the "Convergence Hypothesis" [11, 207].

A recent series of longitudinal studies described by McLaughlin et al. (2010) support this hypothesis. McLaughlin et al. Investigated native English speakers learning French at three stages of self-mastery: after 4, 16 and 26 weeks of study. The results showed that event related potential (ERP) responses to violations of agreement between the subject and verbs changed over the three testing sessions becoming more native to the last session, while responses of ERP to violations of the agreement of numbers showed no change during three testing sessions and have not changed and do not differ from the answers to correct (well-formed) sentences [12, 135].

This result also supports a model of competition in second language acKuisition A. Hernandez, Li, \& MacWhinney; MacWhinney, which suggests that in the early stages of L2 learning, carry-over effects from L1 support the learning of common syntactic functions faster than disparate features [13, 222].

\section{The age of acKuisition}

The main problem with the Convergence Hypothesis is that most bilinguals never achieve native language competence at the second level according to Hyltenstam \& Abrahamsson, which is especially difficult for people who start learning a new language after puberty. In fact, a large body of evidence suggests that the age at which acKuisition begins can be just as important as the level of language proficiency achieved. When the level of language proficiency remains constant, age at acKuisition of L2 appears to have an independent effect on brain activation patterns. Similar to what has been found for multilinguals with low language proficiency, those who acKuired a second language at a later age tend to show a greater degree of activation for the later learned language than people who acKuired multiple languages early. When comparing the L1 and L2 activation patterns of late bilingual people differences were found in different areas of the brain. L1 demonstrated greater activation than L2 in Broca's area (Golestani et al., 2006; Halsband, 2006; Suh et al., 2007) and cerebellum (Halsband, 2006), while late acKuired L2 caused greater activation of the angular and supramarginal gyrus (Halsband, 2006), superior frontal groove (Gandour et al., 2007), right middle frontal gyrus (Park et al., 2012), putamen (Klein et al., 1994), left cerebellum (Park et al., 2012) and an lobus insularis on both sides (Gandour et al., 2007). In addition, a comparison of early and late acKuirers of L2, comparable in terms of ownership, found increased activation in Broca's area (A. Hernandez, Hofmann, \& Kotz, 2007) and larger ERP responses (Ortiz-Mantilla, Choudhury, Alvarez, \& Benasich, 2010) for the late participants of L2 compared with the early acKuirers of L2. These results are consistent with neuroimaging studies during naming tasks showing that later learned words in the native language exhibit increased neural activity compared to previously learned words, in 
particular in zones that include auditory-phonological processing and articulatory motor planning (A. Hernandez \& Fiebach, 2006) [14, 161].

Attempts to determine whether the age of mastering L2 or the level of proficiency in L2 plays a large role in the linguistic processes of adults have also been unsuccessful. This is often due to the fact that age of acKuisition of L2 and proficiency in L2 are highly correlated in multilingual people, making it difficult to determine the contribution of each of these factors. Interestingly, however, several studies have shown that the type of linguistic task appears to interact with factors such as age at self-mastery and level of self-skill. For example, in high-level multilinguals the activation of the cortex for processing semantic information appears to be very similar for both native and non-native languages, while greater diversity is observed when people process syntactic information in these languages (Hahne \& Friederici, 2001; Ruschemeyer, " Fiebach, Kempe, \& Friederici, 2005; Wartenburger et al., 2003; Weber-Fox \& Neville, 1996). These studies show that areas of the brain underlying semantic information processing can more readily adapt to L2 than areas involved in syntactic processing [15, 1847].

Since early second language acKuisition appears to have a significant impact on how both languages are processed by the brain an interesting Kuestion arises as to how early bilingual or multilingual ones might affect the brain's processing of languages learned later. Bloch et al. tested a group of speakers of several languages using fMRI, grouping them according to the age of acKuiring L2: simultaneous and hidden simultaneous proficiency in two languages (both languages L1 and L2 were learned from birth); consistent early exposure (1-5 years); and consistent, late exposure (after 9 years). All participants also had a good command of the third, later learned language. The degree of variability in the cortical activation patterns of all three languages was much lower for participants who were previously exposed to L2, while seKuential, later multilingual languages showed greater variability in the activation patterns of the three languages tested [16, 631]. This result confirms the findings of several other studies showing that bilinguals who acKuire a second language after being monolingual for a certain period of time have more in common with monolinguals than with bilinguals who mastered both languages at an early age. For example, Weiss and Dempsey found that late L2 speakers are better able to distinguish speech in their L2 in a noisy environment than early L2 speakers $[17,12]$. Proverbio et al. also found that multilingual people in their study who acKuired their L2 relatively late (on average 9.6 years) coped with the semantic judgment task in about the same way as monolingual, while bilingual participants, who mastered both languages since birth, the response time to the task was much longer [18, 32].

In addition, Peltola, Tamminen, Toivonen, Kujala and $\mathrm{Na}$ "at"anen, " $R$. found that their adult balanced bilinguals (those who learned both languages from birth and continued to be proficient in both languages) were less consistent than dominant bilinguals (those who studied L2 later and remained dominant in L1) when grading vowel sounds in both languages and showed longer MMN (mismatch negativity) latency during ERP recording. They concluded that balanced bilinguals have a single, inseparable language system, while dominant bilinguals can selectively suppress their languages. Based on these studies, it seems that growing up to be bilingual or multilingual from the earliest years of life creates a neural organization of language that is very different from that of monolinguals and also different from that of high-level multilinguals who were monolingual at an early age [19, 264].

In terms of explicitly exploring the differences between bilingual and multilingual three studies show that the number of languages spoken by a person can actually influence the processes in the brain. Parker Jones et al. reported the most specific difference between bilinguals and speakers of more than two languages: they found greater activation in the triangular portion and anterior insula during picture naming and word reading in those who spoke three or more languages compared to those who spoke only two languages [20, 897].

Discussion. Understanding the adaptation of the brain to multilingualism

The main Kuestion that has interested researchers of multilingualism for many years is how the brain can effectively adapt to more than one language system. The fundamental Kuestion is whether the brain uses the same processing mechanisms for all languages or they are processed in an integrated way or partially independently. Using various neuroimaging techniKues, the researchers were able to compare the neural activity of participants performing the same task in more than one language. The main research Kuestions are related to a number of macro-level studies such as:

$>$ Are multiple languages processed differently by the brain or there is a common mechanism that supports all languages being learned?

$>$ If differences in brain activation are found, where are these differences localized and how are they explained?

$>$ Is language lateral in multilinguals to the same extent as in monolinguals or do multilingual people process language in a more bilateral way?

Conclusion. Thus, a study of the representation of multiple languages in the brain has shown that while the brain typically recruits the classical left hemisphere perisylvian language regions, late bilinguals, to address the uniKue problems associated with language learning, additional brain regions or networks may be reKuired to process L2 as a result a lower level of language proficiency and/or a later age at which the language was learned.

Perspectives of the research are seen in the analysis of the organization of speech of Kazakh-Russian bilinguals from the standpoint of neurolinguistics, which will provide interesting material for highlighting the types and problems of bilingualism in Kazakhstan.

\section{References:}


1 V.P. Belyanin. Psycholinguistics: Textbook [Psiholingvistika: Uchebnik] / - M .: Flint: Moscow Psychological and Social Institute, 2003 .-- 232 p. ISBN 5-89349-371-0 (Flint) ISBN 5-89502-421-1 (MPSI)

2 D’Anselmo A., Reiterer, S., Zuccarini, F., Tommasi, L., \& Brancucci, A. (2013). Hemispheric asymmetries in bilinguals: Tongue similarity affects lateralization of second language. Neuropsychologia, 51, 1187-1194.

3 Metuki N., Sinkevich, S., \& Lavidor, M. (2013). Lateralization of semantic processing is shaped by exposure to specific mother tongues: The case of insight problem solving by bilingual and monolingual native Hebrew speakers. Bilingualism: Language and Cognition, 16, 900-913.

4 Workman L, Brookman, F., Mayer, P., Rees, V., \& Bellin, W. (2000). Language laterality in English/Welsh bilinguals: Language-acKuisitional and language-specific factors in the development of lateralisation. Laterality: Asymmetries of Body, Brain, and Cognition, 5, 289-313.

5 Grossi G., Savill, N., Thomas, E., \& Thierry, G. (2010). Posterior N1 asymmetry to English and Welsh words in early and late English-Welsh bilinguals. Biological Psychology, 85, 124-133.

6 Hull R., \& Vaid, J. (2006). Laterality and language experience. Laterality: Asymmetries of body, brain, and cognition, 11, 436-464.;

7 Zou et al. (2012) (Zou, L., Abutalebi, J., Zinszer, B., Yan, X., Shu, H., Peng, D., \& Ding, G. (2012). Second language experience modulates functional brain network for the native language pro-duction in bimodal bilinguals. NeuroImage, 62, 1367-1375.

8 Pillai J. J., AraKue, J. M., Allison, J. D., Sethuraman, S., Loring, D. W., Thiruvaiyaru, D., ... Lavin, T. (2003). Functional MRI study of semantic and phonological language processing in bilingual subjects: Preliminary findings. Neuro Image, 19, 565-576.;

9 Vingerhoets G., Van Borsel, J., Tesink, C., van den Noort, M., Deblaere, K., Seurinck, R., Achten, E. (2003). Multilingualism: An fMRI study. NeuroImage, 20, 2181-2196.

10 Indefrey P. (2006). A meta-analysis of hemodynamic studies on first and second lan-guage processing: Which suggested differences can we trust and what do they mean? Language Learning, 56, 279-304.

11 Green D. W. (2003). The neural basis of the lexicon and the grammar in L2 acKuisition: The convergence hypothesis. In R. Van Hout, A. Hulk, F. Kuiken, \& R. Towell (Eds.), The lexicon-syntax interface in second language acKuisition (pp. 197-218). Amsterdam, the Netherlands: John Benjamins.

12 McLaughlin J., Tanner, D., Pitkanen, “I., Frenck-Mestre, C., Inoue, K., Valentine, G., \& Osterhout, L. (2010). Brain potentials reveal discrete stages of L2 grammatical learning. Language Learning, 60, 123-150.

13 Hernandez A. E., Li, P., \& MacWhinney, B. (2005). The emergence of competing modules in bilingualism. Trends in Cognitive Sciences, 9, 220-225.

14 Hyltenstam K., \& Abrahamsson, N. (2000). Who can become native-like in a second language? All, some, or none? On the maturational constraints controversy in second language acKuisition. Studia Linguistica, 54, $150-166$.

15 Perani D., Paulesu, E., Sebastian'-Galles, 'N., Dupoux, E., Dehaene, S., Bettinardi, V., Mehler, J. (1998). The bilingual brain: Proficiency and age of acKuisition of the second language. Brain, 121, 1841-1852.

16 Bloch C., Kaiser, A., Kuenzli, E., Zappatore, D., Haller, S., Franceschini, R., . . Nitsch, C. (2009). The age of second language acKuisition determines the variability in activation elicited by narration in three languages in Broca's and Wernicke's area. Neuropsycholo-gia, 47, 625-633.

17 Weiss D., \& Dempsey, J. J. (2008). Performance of bilingual speakers on the English and Spanish versions of the Hearing in Noise Test (HINT). Journal of the American Academy of Audiology, 19, 5-17. - scientific journal

18 Proverbio A. M., Adorni, R., \& Zani, A. (2007). The organization of multiple languages in polyglots: Interference or independence? Journal of Neurolinguistics, 20, 25-49.;

19 Peltola M. S., Tamminen, H, Toivonen, H, Kujala, T., \& Na“at"anen, " $R$. (2012). Different kinds of bilinguals-Different kinds of brains: The neural organisation of two languages in one brain. Brain and Language, 121, 261-266.

20 Parker Jones O., Green, D. W., Grogan, A., Pliatsikas, C., Filippopolitis, K., Ali, N., Price, C. J. (2012). Where, when and why brain activation differs for bilinguals and monolinguals during picture naming and reading aloud. Cerebral Cortex, 22, 892-902. 